\title{
Legal Protection for Outsourcing Workers
}

\author{
Titin Saptini ${ }^{1}$, Rineke Sara ${ }^{2}$ \\ \{Tinskero@gmail.com ${ }^{1}$,rineke_sara@borobudur.ac.id ${ }^{2}$ \} \\ Universitas Borobudur Jakarta, Indonesia ${ }^{1,2}$
}

\begin{abstract}
This article discusses the legal protection for outsourced workers as regulated in Law No. 13 of 2003. By using a qualitative approach and normative juridical research methods, as well as using literature studies to collect the data, and then be analyzed descriptively which then resulting in a comprehensive analysis. The results found that the existing regulations had protected the workers' rights, but on the other hand, there were weaknesses in the implementation of praxis concerning the working relationship of workers and employers.
\end{abstract}

Keywords: Law; Labor; Outsourcing

\section{Introduction}

Indonesia officially beginning around 1945 (the pre-alteration Constitution) has announced itself as a lawful state and has been reaffirmed in the 1945 Constitution of the Republic of Indonesia (from this point forward alluded to as the 1945 Constitution of the Republic of Indonesia) in Articles 1 and 3 expressed that: "Indonesia is the State of Law." Thus, by taking into account the formulation of the concept of the rule of law in Indonesia, Ismail Suny noted four requirements for the state of law formally are the government's obligation to implement, namely, Human Rights, Division of Power, Government based on Laws and Administrative Courts,[1] as a state of law, then, every society has the same position to each other without any differences (equality before the law).

Insurance of laborers/laborers is an indivisible piece of the security of residents as a state commitment. Essential freedoms as individuals should be satisfied by getting insurance any place, they work to get their key privileges. Both the situation with residents is unique, and the resident's status is the equivalent so they get a respectable life as an individual after Article 28 D Paragraph 3 of the 1945 Constitution of the Republic of Indonesia, that: "Each resident has the privilege to work and get reasonable and appropriate pay and treatment. in a functioning relationship."

In the relationship between workers/workers and entrepreneurs, the law of autonomy and heteronomy applies, and the existence of this law of autonomy and heteronomy is what gives birth to labor law which is private law and public law. The nature of private law means that labor law regulates the relationship between workers and employers in which each party is free to determine the form and content of the working relationship between them. Public law shows the existence of coercive legal regulations that must be obeyed by employers and workers if they have intercourse before, during, and after the work period.[2] 
The employment system in Indonesia also allows the outsourcing of labor, but it is used more to meet the needs in terms of the number of employees, giving rise to the assumption that outsourced workers only rely on muscles rather than brains or, in other words, with low education, struggling in areas of work that are not too important and minimum income. The working relationship between the worker and the entrepreneur that arises because of a work agreement is theoretically the right of the entrepreneur and the worker to start or end it. However, for workers, the legal relationship that occurs with the employer is always in a subordinate relationship or a relationship where the worker's position is lower than the employer or employer. For outsourced workers, this is getting worse because the workers do not have a working relationship with the employer company.

The working relationship at this time is generally called a flexible working relationship, in the sense that the current working relationship does not provide a guarantee of certainty whether a person can work continuously and other matters relating to his rights. Flexibility bias concerns the time to do work which is not always tied to the working hours determined by the employer but determined by the workers. In practice, it initially found that there were four types of flexible working relationships, namely:

a. Employment relationship based on a work delivery or loan agreement;

b. Work relations carried out at home;

c. Free employment relationship;

d. A working relationship based on the call.

The definition or meaning of re-appropriating in a business relationship isn't found in Law Number 13 of 2003 concerning Manpower. However, Article 64 of the Law expresses that an organization might give up a piece of the execution of work to one more organization through a task contract arrangement or the administrations arrangements for laborers/workers made recorded as a hard copy. From this depiction, it very well may be presumed that the reappropriating framework is an adaptable working relationship dependent on sending or acquiring laborers. This paper will examine the legitimate insurance of re-appropriated laborers as directed in Law No. 13 of 2003.

\section{Method of Study}

This legitimate composing is regularizing lawful examination, the information wellsprings of this lawful composing remember research for lawful standards, lawful systematics, level of lawful synchronization, and lawful correlation.

\section{Discussion}

Law No. 13 of 2003 concerning Manpower, the word outsourcing is not mentioned directly, but it is stated as handing over as work to other companies. Outsourcing is a term commonly used in the industrial world with more or less the same meaning as the meaning outlined by the labor law. [2] The task of work to different organizations or re-appropriating is directed in Article 64, Article 65 (comprising of 9 sections), and Article 66 (comprising of 4 passages). The articles on re-appropriating in the Manpower Act give re-appropriating bearings as follows:

a. Types of outsourcing.

b. Outsourcing formal requirements. 
c. Requirements for the service provider company/labor.

d. Guarantee the welfare of employees/ laborers in service providers/ laborers.

The arrangements regarding outsourcing in Law 13 of 2003 concerning Manpower have developed from the orders contained in the Civil Code, which started from the rental of servants and workers that is included in book III of the Civil Code where the services of servants or workers were equated with assets. By setting the law, the purpose of the regulation is more towards the human aspect or the protection of workers. The description of an understanding of the articles regarding outsourcing in Law 13 of 2003 concerning Manpower is as follows [3]:

Article 64 of Law Number 13 of 2003 concerning Manpower depicts the sorts of reappropriating as Companies can give up piece of the execution of work to different organizations through work sanctioning arrangements, or the arrangement of laborers/work administrations are made recorded as a hard copy. The clarification of the Article expressed obviously so an end can be drawn that reevaluating or in the law had expressed as a feature of the execution of the organization's work, which is partitioned into two fields, specifically contracting work arrangements and giving specialists/work administrations.

Article 65 of Law Number 13 of 2003 concerning Manpower directs explicit positions that are submitted to different organizations or can likewise be alluded to as limitations on reappropriating exercises, as expressed in Article 65 section (1) to passage (9) of the Law. Law Number 13 of 2003 concerning Manpower. Moreover, in regards to Article 66 passage (1), the Elucidation of the Law gives additional data as adheres to: In business related to principal business exercises or exercises straightforwardly identified with the creation cycle, business visionaries are simply permitted to utilize laborers/workers with a work understanding for a particular time frame nor an endless term of a work arrangement.[3]

The significance of supporting assistance exercises or exercises not straightforwardly identified with the creation interaction are exercises related external the center business of a task. These exercises included cleaning administration business, catering business for laborers/workers, security staff business (security unit), supporting assistance business in mining and petrol, just as the matter of giving specialist/work transportation. [4]

In the Manpower Act, there are some formal requirements for outsourcing that employers must pay attention to. These requirements can be seen in the provisions stated in Article 65 paragraph (1) to paragraph (7). Laborers/work specialist co-ops for supporting help exercises or exercises that are not straightforwardly identified with the creation cycle should meet the accompanying prerequisites:[3]

a. The presence of a functioning connection between the specialist/worker and the specialist organization for the laborer/worker;

b. The appropriate work understanding in the business relationship as alluded to in letter a will be a work arrangement for a particular time frame that meets the prerequisites as alluded to in Article 59 nor an endless work arrangement made recorded as a hard copy and endorsed by the two players;

c. Pay and government assistance assurance, working conditions, and debates that emerge are the obligation of the specialist/work specialist co-op organization;

d. Arrangements between organizations that utilize specialist/work administrations and different organizations that go about as organizations giving laborers/work administrations are made recorded as a hard copy and should contain the articles as alluded to the law.

The reevaluating plan for the conveyance of part of the work execution to different organizations as indicated by the Manpower Law in Indonesia is managed in Article 64 of Law No. 13 of 2003 concerning Manpower, a Company might give up piece of the execution 
of work to different organizations through work contracting arrangements or the arrangement of specialist/work administrations made recorded as a hard copy.[5] Based on the stipulations of the article above, outsourcing is divided into two forms of business agreements, namely the chartering of work and the provision of worker or labor services.

The relation between outsourced employees and companies that use workers' services resulted in an agreement between companies that employ workers' services and the outsourcing company where the employee is registered as an employee. Legally, there is no working relationship between the Outsourced employees who are placed and the company that uses the workers' services.

Reevaluated representatives who are put in organizations that utilize specialist administrations are needed to consent to Company Regulations or Collective Labor Agreements that apply to the organization. Organization guidelines are a type of freedoms and commitments for organizations and laborers. Freedoms and commitments arose out of a work relationship. To do the work emerging from the re-appropriating arrangement, the current lawful connection between the help client organization and the re-appropriating organization to complete the work. Laborers don't have a lawful relationship with organizations that utilization laborers' administrations however with rethinking organizations.

Company regulations contain rights and obligations between companies and outsourced employees. The rights and obligations describe a legal relationship between workers and the company, in which both parties are bound by a mutually agreed work agreement. Meanwhile, the existing legal relationship is between an outsourcing company and a service user company in a consent to provide workers. Companies that use workers' services and employees do not have a direct working relationship, either in the form of a work agreement for a specific time or a work agreement for an indefinite time. When viewed from the terminology of the nature of the implementation of the Company Regulations, the company regulations of the service user companies cannot be applied to outsourced employees because there is no working relationship. The working relationship that occurs is a working relationship between outsourced employees and outsourcing companies. So, outsourcing employees should use the outsourcing company's stipulations and not the company's regulations that use worker services.

Under the above understanding, what is meant by an outsourcing agreement is a business agreement between one company (can also be an individual) and another company (must be a legal entity) for a mutual agreement regarding the delivery of part of the implementation of the work. So, what is meant by outsourcing workers are workers who work for a company that provides workers' services or a company that accepts job chartering. The protection of outsourced workers is highly dependent on the consistent and continuous application of the applicable provisions, the supervisory function of each labor inspector in the district/city and province.

\section{Conclusion}

Lawful assurance for reevaluated laborers has been contained in the work law and afterward reaffirmed in the Constitutional Court Decision. Reevaluating is a sensible business strategy of an organization with regards to business productivity. Nonetheless, laborers who work in reevaluating organizations should not lose their privileges secured by the constitution. So, laborers are not taken advantage of, in its thought, the Constitutional Court offers two reevaluating models, specifically necessitating that the work arrangement among laborers and 
organizations that complete re-appropriating work isn't as a proper time work understanding (PKWT). However, as an unclear work arrangement (PKWTT) and the instance of the business connection among laborers and reevaluating organizations dependent on PKWT, the work understanding should require the exchange of security of freedoms for laborers whose objects of work stay, despite the fact that there is an adjustment of the organization that does some portion of the piece work from another organization or an organization that offers laborers' types of assistance.

\section{References}

[1] T. T. Tutik, Pokok-pokok Hukum Tata Negara [Basics of Constitutional Law]. Jakarta: Prestasi Pustaka. (2006).

[2] D. Agus, Hukum Ketenagakerjaan [Labor Law]. Serang: Dinas Pendidikan Provinsi Banten. (2012).

[3] "Law Number 13 of 2003 concerning Manpower, State Gazette of the Republic of Indonesia of 2003 Number 39 and Supplement to the State Gazette of the Republic of Indonesia Number 4279."

[4] Z. Asikin, Dasar-Dasar Hukum Perburuhan [Labor Law Basics]. Jakarta: Raja Grafindo Persada. (2008).

[5] Soepomo, "Introduction to Labor Law.” Djambatan, Jakarta. (2003). 